\title{
Lower third molar fused with a supernumerary tooth: diagnosis and treatment planning using Cone-Beam Computed Tomography
}

\author{
Terceiro molar inferior fusionado com um supranumerário: diagnóstico e plano de tratamento usando \\ Tomografia Computadorizada Volumétrica
}

Osny FERREIRA-JÚNIOR'

Luciana Dorigatti de ÁVILA'

Marcelo Bonifácio da Silva SAMPIERI ${ }^{1}$

Eduardo DIAS-RIBEIRO'

\begin{abstract}
Fusion is the union of two developing dental germs, resulting in a single large dental structure. It involve two normal dental germs or the germ of a normal tooth with a germ of a supernumerary one. Supernumerary teeth are additional teeth of the normal series which may occur in any region of the dental arch, althoug they are more common in the maxilla than in the mandible. This article presents a case of fusion between a third molar and a supernumerary tooth, in which a surgical intervention was carried out, with the objective of removing the dental elements The panoramic radiography was complemented by the Donovan's radiographic technique, but because of the proximity of the dental element to the mandibular ramus, it was not possible to have a final fusion diagnosis. Hence, the Cone-Beam Computed Tomography which provides precise three-dimensional information, was used to determinate the fusion diagnosis and also to help in the surgical planning.
\end{abstract}

Indexing terms: Cone-Beam computed tomography. Supernumerary tooth. Surgery oral. Third molar.

\section{RESUMO}

Fusão é a união de dois germes dentários em desenvolvimento, resultando numa única estrutura dentária, podendo ocorrer entre dois germes dentários normais ou entre o germe de um dente normal com um supranumerário. Dentes supranumerários são dentes adicionais à série normal e podem ocorrer em qualquer região da arcada dentária, entretanto, são mais comumente encontrados na maxila do que na mandíbula. O presente artigo ilustra um caso de fusão entre um terceiro molar mandibular e um dente supranumerário, onde foi realizada uma intervenção cirúrgica com o objetivo de remover os elementos dentários. Para complementar o diagnóstico, além da radiografia panorâmica, utilizou-se a técnica radiográfica de Donovan, mas, devido à proximidade do elemento dental com o ramo mandibular, não foi possível determinar um diagnóstico preciso de fusão. Sendo assim foi utilizada a Tomografia Computadorizada Volumétrica que fornece informações precisas e em três dimensões, possibilitando desta forma chegar ao diagnóstico de fusão e também auxiliando no planejamento cirúrgico.

Termos de indexação: Tomografia computadorizada de feixe cônico. Dente supranumerário .Cirurgia bucal. Dente serotino.

\section{INTRODUCTION}

Supernumerary teeth are additional teeth in the normal series which may occur in any region of the dental arch althoug they are more frequent in the maxilla than in the mandible ${ }^{1-6}$. They are considered uncommon and occur with a frequency of 0.3 to $3.8 \%$ in the population ${ }^{7}$ and they are classified according to their position and form. According to their location they are named mesiodens, paramolars, parapremolars and distomolars ${ }^{6,8}$. Concerning to their form they are named eumorphic, rudimentar or dysmorphic, tuberculous and conical6,9.

Fusion is the union of two developing dental germs resulting in a single large dental structure ${ }^{10}$.
It may be consisted of a germ of a normal tooth with a supernumerary one or with two normal dental germs $s^{1,10-12}$. The pulpar chambers and canals may occur either separated or together according to the formation stage at the moment of the union. If this union occurs precociously the crowns will be together, with separate roots resulting in a big dental structure. If the union happens after the crown formation, the roots will probably be together ${ }^{13}$.

The dental fusion etiology remains unknown and may be originated from either genetic or environmental factors ${ }^{1-3,8,10,12-15}$. However some authors suggest that it may occur due to strength or pressure over the germs of adjacent teeth during their development which produces a tissue necrosis as a consequence. This could

\footnotetext{
${ }^{1}$ Universidade de São Paulo, Faculdade de Odontologia, Departamento de Cirurgia e Traumatologia Buco-Maxilo-Facial e Periodontia. Al. Octávio Pinheiro Brisola, 9-75, 17012-901, Bauru, SP, Brasil. Correspondência para / Correspondence to: E DIAS-RIBEIRO. E-mail: <eduardodonto@yahoo.com.br>.
} 
make the enamel organ and the dental papillae of two teeth to produce a sole tooth ${ }^{14,16}$. This phenomenon may affect $0.5 \%$ to $1 \%$ of the population ${ }^{3,13}$ and may also affect both dentitions, specially in the region of incisors and canines. In relation to the permanent dentition the prevalence of fused teeth corresponds to $0.2 \%$ and $0.05 \%$ with the deciduous dentition presenting a higher occurrence ${ }^{2,13}$.

In addition, there is also a difference between fusion and germination. The latter results from a failure in the division of a dental follicle, generating a big bifid crown tooth, which usually presents roots and canals in common. The fusion presents at least two ducts and two roots for the same pulpal chamber'12,13,15,17.

Nevertheless these definitions are not enough to precisely distinguish fusion and gemination, between a "normal" tooth and a supernumerary one. The final diagnosis can be obtained with both clinical and radiographic findings ${ }^{18}$.

This article reports a clinical fusion case between a third and a fourth lower molars, diagnosed through Cone-Beam Computed Tomography (CBCT). Before the surgical procedure the patient was asked to sign the Consent Term, following the ethical principles in the Helsinki declaration (2000).

\section{CASE REPORT}

A 26-year old leukoderm female patient came to Bauru Dental School (FOB/USP Bauru, São Paulo, Brazil) asking for surgery assistance to the exodontic treatment for her third molars. During anamnesis she reported the use of iron sulfate because of iron deficiency anemia, and the use of fluoxetin hydrochloride, for the treatment of pre-menstrual tension.

According to the physician the patient was able to undergo surgical procedures, since her coagulation presented normal, and she was told to not use fluoxetin on the day of ther surgery. The clinical exam presented tooth 48 partially erupted while the panoramic radiography showed the presence of a fourth molar (Figure 1). An occlusal radiography was taken to assess the relation between the fourth and the third molar, but it wasn't possible to obtain more details because the fourth molar was too close to the mandibular ramus. The Donovan's technique permitted to visualize two close crowns, however without establishing whether there was a union between them (Figure 2).

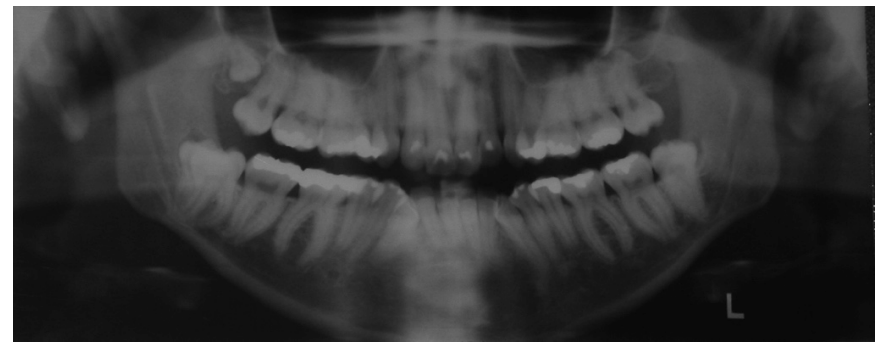

Figure 1. The panoramic radiograph shows the presence of the third and fourth molars

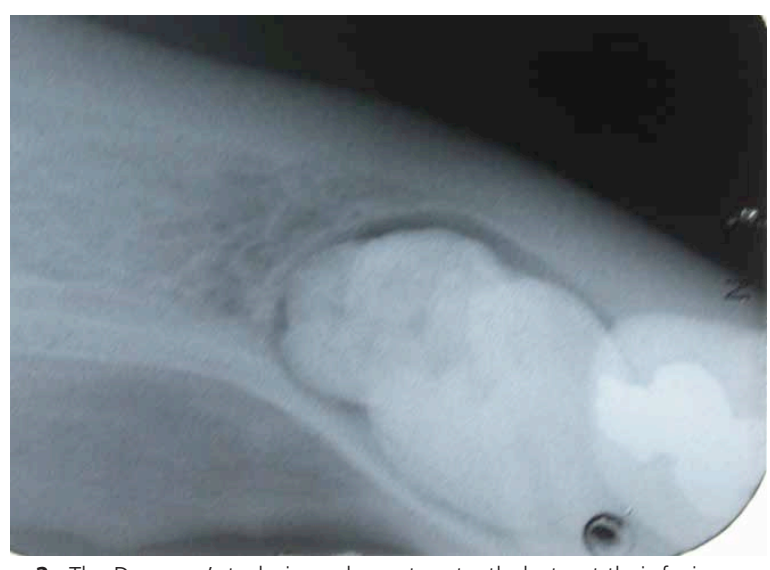

Figure 2. The Donovan's technique shows two teeth, but not their fusion.

A CBCT was then suggested to establish whether there was fusion, gemination, or they were two distinct teeth, and also to carry out a suitable surgical planning. This exam permitted visualize a fusion between the teeth and a close relation of their roots with the lower alveolar nerve (Figure 3).

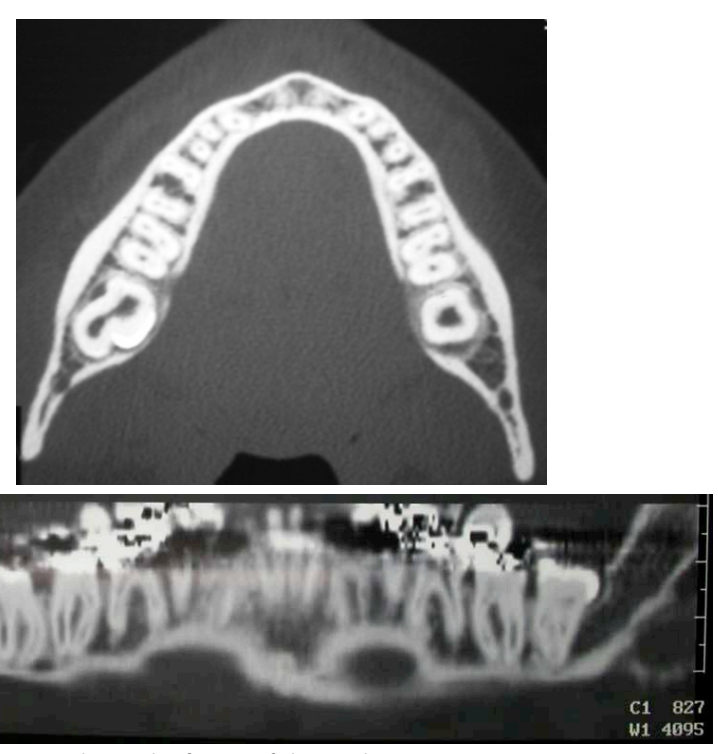

Figure 3. The $\mathrm{CBCT}$ shows the fusion of the teeth 
The patient was informed about the risks of the surgery, accepted them and signed the consent term. Prior to the surgery an intrabuccal and extrabuccal antisepsis was performed with $0.12 \%$ and $2 \%$ Chlorexidine, respectively. The sterile operating field was placed. The anesthesia was administered to the lower alveolar, lingual and buccal nerves employing the three-position technique, with $4 \%$ articaine hydrochloride ${ }^{19}$.

An Avellanal incision was performed 20,21 with an oblique incision on the mesial face of the second molar, the mucoperiosteum was detached, the osteotomy was performed with a \# 6 carbide bur and the teeth were sectioned with a \# 4138 diamond bur applying high rotation under cooling. The fused teeth were separated into three fragments because of their size and the number of roots and then extracted (Figures 4).

The postoperative medicine prescribed was Amoxicillin 500mg, every 8 hours, by 7 days; Celebra $200 \mathrm{mg}$, every 12 hours, by 3 days and, in case of pain Dipyrone Sodium 500mg, every 4 hours.

After four days the patient returned to the clinic complaining about a lower right lip paresthesia which disappeared 15 days after. She was followed during the next month and did not present any other problem.

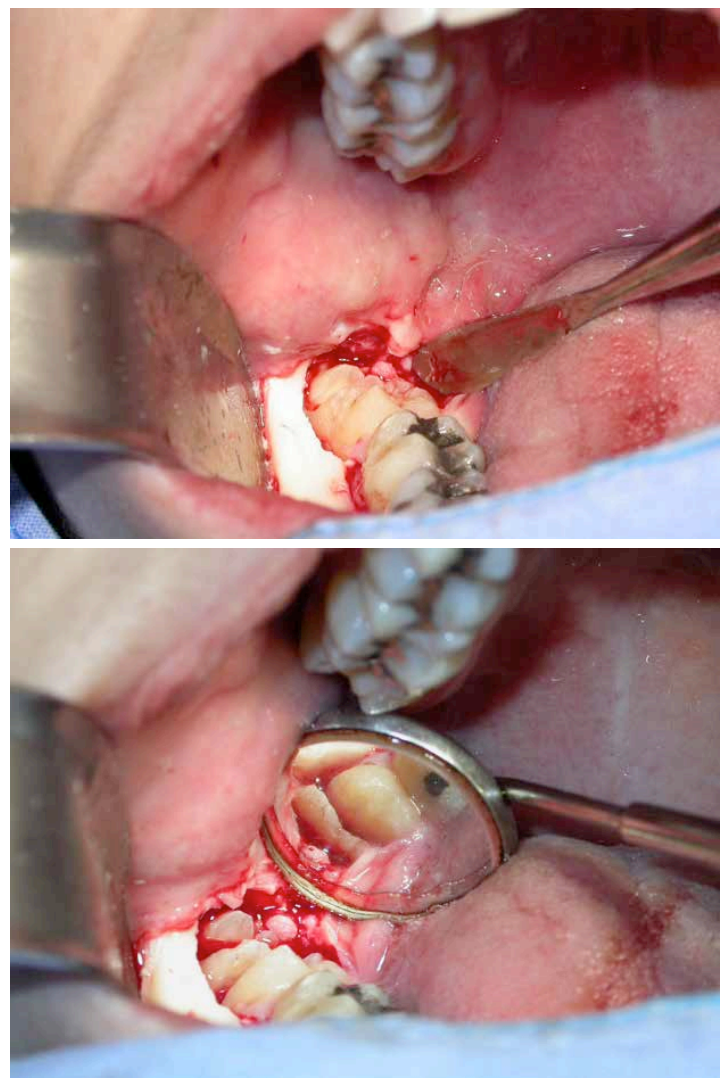

Figure 4. Transoperative.

\section{DISCUSSION}

The present clinical case is a rare example of a fusion between a lower third molar and a fourth supernumerary one. According to their shape they may be classified as eumorphic (shape and size of a tooth in the normal series), rudimentar or dysmorphic (smaller and malformed), tuberculous (more than a cusp or tubercle), and conical ${ }^{9,22-23}$. They fusion may occur in any region of the dental arch though it is more frequent in the premaxilla 22,24 . The upper molars' region is the second most common location and the patient in this case also presented a fourth upper molar on the right side.

The most common region is the incisors and canines region and the fusion of permanent posterior teeth is rare. The prevalence of fused teeth in the permanent dentition is $0.2 \%$ (unilateral) and $0.05 \%$ (bilateral) ${ }^{13}$.

Most cases of fused teeth are asymptomatic and many times they are discovered only through clinical or radiographic exams, nevertheless, Mader ${ }^{12}$ reported that the fusion may cause clinical problems related to aesthetics, the loss of space in the dental arch and periodontal problems. It is very important to identify and to enumerate the fused teeth both clinically and radiographically in order to plan a safe treatment.

Periapical, occlusal and panoramic radiographs generally provide the necessary information, however these images are not as precise as the three-dimensional ones. If the findings suggest high injury risks to the lower alveolar nerve, exams through additional images must be included in order to observe the anatomical relation between the root and the alveolar canal25-26.

The CBCT permits to execute three-dimensional reconstructions providing information on axial, sagittal and coronal planes ${ }^{26}$. Besides it clearly shows the anatomical relation of the mandibular canal with the third molar, the pattern and the morphology of non-erupted or supernumerary teeth, as well as their relation to adjacent teeth, maxillary sinus and mandibular canal ${ }^{18,27}$. Finally it is necessary to point out that comparisons among images techniques showed that Computed Tomography produced more complete information than the conventional radiographs. Nevertheless the conventional equipment of Computed Tomography was not originally developed for dental use. Thus there are some problems such as high costs, the need of space, the long exposition 
time and also a high radiation level, to use this appliance in the dentistry field ${ }^{18,27}$.

In recent years the $C B C T$ has innovated the concept of dentistry imaging, allowing threedimensional reconstruction of a patient's face and skull. The new generation equipments permit the visualization of soft and hard tissues, surpassing conventional images in relation to the linear measurements of maxillaries, the location and the extension of dental resorptions, the radicular position, the presence of radicular fractures, the diagnosis of bone lesions, etc. Therefore these equipments allow a general view of the maxillomandibular complex. Besides these advantages, it utilizes a conical beam system of $\mathrm{x}$-rays which exposes the patient to a single circular movement, and then to a smaller radiation level with faster acquisition of images and lower $\operatorname{costs}^{28}$. Hence the CBCT that is an important exam to provide the necessary information for the surgical planning and to protect the patient against unnecessary risks ${ }^{26}$ was employed in this case.

\section{REFERENCES}

1. Abrams RA, Nelson DL. Fusion of a third molar to a supernumerary tooth with an associated dentigerous cyst. Aust Dent J. 1979;24(3):141-2. doi: 10.4103/0973-029X.92991

2. Shafer WG, Hine MK, Levy BM. A textbook of oral pathology. $4^{\text {th }}$ ed. Philadelphia: Saunders; 1993.

3. Hamasha AA, Al-Khateeb T. Prevalence of fused and geminated teeth in Jordanian adults. Quintessence Int. 2004;35(7):556-9.

4. Fernandes AV, Rocha NS, Almeida RAC, Silva EDO, Vasconcelos BCE. Quarto molar incluso: relato de caso. Rev Cir Traumatol Buco-Maxilo-Fac. 2005;5(2):61-6.

5. Harris EF, Clark LL. An epidemiological study of hyperdontia in American blacks and whites. Angle Orthod. 2008;78(3):460-5. doi: 10.2319/022807-104.1

6. Rajab LD, Hamdan MA. Supernumerary teeth: review of the literature and a survey of 152 cases. Int J Paediatr Dent. 2002;12(4):244-54. doi: 10.1046/j.1365-263X.2002.00366.x

7. Salcido-García JF, Ledesma-Montes C, Hernández-Flores F, Pérez $D$, Garcés-Ortíz M. Frequency of supernumerary teeth in Mexican population. Med Oral Patol Oral Cir Bucal. 2004;9(5):407-9.

8. Neville BW, Damm DD, Allen CM, Bouquot JE. Oral and maxillofacial pathology. $2^{\text {nd }}$ ed. Philadelphia: Saunders; 2002.

9. Liu JF. Characteristics of premaxillary supernumerary teeth: a survey of 112 cases. ASDC J Dent Child. 1995;62(4):262-5.

\section{CONCLUSION}

In the case reported it was observed that the traditional radiographic exams (periapical, occlusal and panoramic) are not able to show details which could only be observed through the CBCT. This case report emphasizes the need to use this new diagnostic hardware to help in the treatment planning of the oral and maxillofacial surgery.

\section{Collaborators}

O FERREIRA-JÚNIOR participated in the guidance, assistance in preparing the manuscript, patient operation and writing the article. LD ÁVILA assisted in the photographs in the pre-and post-operative, literature, in the preparation and writing of the manuscript. MBS SAMPIERI assisted in surgery, in literature, in the preparation and writing of the manuscript. E DIAS-RIBEIRO assisted in the post-operative care, in literature, in the preparation and writing of the manuscript.

10. Regezi JA, Sciubba JJ. Oral pathology: clinical pathologic correlations. $3^{\text {rd }}$ ed. Philadelphia: Saunders; 1999.

11. Chen HS, Huang YL. Fusion of third and fourth mandibular molars? Oral Surg Oral Med Oral Pathol. 1992;73(6):767. doi: 10.4103/0973-029X.92991

12. Mader CL. Fusion of teeth. J Am Dent Assoc. 1979;98(1):62-4.

13. Morris DO. Fusion of mandibular third and supernumerary fourth molars. Dent Update. 1992;19(4):177-8.

14. von Arx T. Anterior maxillary supernumerary teeth: a clinical and radiographic study. Aust Dent J. 1992;37(3):189-95. doi: 10.1111/j.1834-7819.1992.tb00741.x

15. Schneider LE, Lima PVP, Grasselli S, Galvagni LE, Quoos A, Hoffmann $M$, et al. Tratamento cirúrgico radical de terceiro e quarto molares fusionados: relato de caso. Rev Cienc Méd Biol. 2006;5(1):80-4.

16. Lowell RJ, Solomon AL. Fused teeth. J Am Dent Assoc $1964 ; 68: 762$.

17. Guimarães Cabral LA, Firoozmand LM, Dias Almeida J. Double teeth in primary dentition: report of two clinical cases. Med Oral Patol Oral Cir Bucal. 2008;13(1):E77-80.

18. Kim KD, Ruprecht A, Jeon KJ, Park CS. Personal computer-based three-dimensional computed tomographic images of the teeth for evaluating supernumerary or ectopically impacted teeth. Angle Orthod. 2002;73(5):614-21.

19. Malamed SF. Handbook of local anesthesia. $4^{\text {th }}$ ed. St. Louis: Mosby; 1997. 
20. Marzola, C. Retenção dental. $2^{\text {a }}$ ed. São Paulo: Pancast; 1995.

21. Martins LD, Lemes CHJ, Zardo M, Egg CMS. Avaliação do reparo periodontal na face distal dos segundos molares inferiores, utilizando dois tipos de incisões para a remoção de terceiros molares retidos. Publ UEPG Ci Biol Saúde. 2007;13(3/4):73-80.

22. Atwan SM, Turner D, Khalid A. Early intervention to remove mesiodens and avoid orthodontic therapy. Gen Dent. 2000;48(2):166-9

23. Grimanis GA, Kyriakides AT, Spyropoulos ND. A survey on supernumerary molars. Quintessence Int. 1991;22(12):989-95.

24. Nazif MM, Ruffalo RC, Zullo T. Impacted supernumerary teeth: a survey of 50 cases. J Am Dent Assoc. 1983;106(2):201-4.

25. Levitas TC. Gemination, fusion, twinning and concrescence. ASDC J Dent Child. 1965;32:93-100.
26. Dodson TB. Role of computerized tomography in management of impacted mandibular third molars. N Y State Dent J. 2005;71(6):32-5.

27. Bayrak S, Dalci K, Sari S. Case report: evaluation of supernumerary teeth with computerized tomography. Oral Surg Oral Med Oral Pathol Oral Radiol Endod. 2005 Oct; 100(4):e65-9. doi:10.1016/j. tripleo.2005.05.065

28. Schmitt S. Virtual diagnostics using cone bean CT. Dent Today 2006;25(6):90-1.

Received on: 27/10/2013

Final version resubmitted on: 11/12/2013

Approved on: 16/2/2014 
